\title{
My view
}

Frank Forcella

USDA Agricultural Research Service,

North Central Soil Conservation Research Laboratory,

803 Iowa Avenue, Morris, MN 56267;

fforcella@mail.mrsars.usda.gov

Weed scientists recently were surveyed for perceptions of weed biology's impact on weed management (Norris 1996; WSSA Abstracts 36:91). Most respondents said that weed biology (1) should be important to weed management, (2) will become increasingly important in the future, but (3) hasn't yet had much effect. Why has weed biology had so little perceived impact on weed management, and what can we do to improve its impact? I think weed biologists have been negligent in revealing the importance of their research. Below, I'll provide simple examples and suggest solutions.

My favorite provocation for weed biologists is seed germination. We typically secure seeds of a beloved species, expose them to various temperatures or water potentials, and after a week or two, we count germinated seeds. Real datamongers count germinated seeds daily. We eventually publish papers with graphs of germination versus temperature. The easiest paper I ever published concerned seed germination of a tropical weed. No problem-but also no theory, no interest, no application, and no one to blame but myself.

There is nothing wrong with publishing articles on seed response to the environment. The literature contains much good weed biology, and better studies are being published. Some papers might even achieve lasting acclaim, but we can expect quick burial of most biology papers in the dusty catacombs of libraries. Extension and industry representatives will not automatically see, read, understand, and implement information on weed biology. These people deal with issues in real time and cannot always afford to decipher biological hieroglyphics. As we accumulate masses of biological information, we must understand that ultimate responsibility for its application rests with the authors who performed the research. Many weed biologists do this too rarely.

How can we use, for instance, graphic expressions of seed germination versus temperature? We might resurrect these data as simple models that predict germination based on daily measurements of soil temperatures. After all, weren't the incubators used in the original studies supposed to simulate soil tempetatures? Exen simple models of environmental regulation of seed germination, rhizome growth, and the like have profound benefits for managing weeds. The johnsongrass studies from Argentina represent excellent, but lonely, examples of utilitarian weed biology research.

"But we're biologists, not modelers," cry weed biologists. "We're supposed to perform basic research, not applied research. Besides, we don't like working with herbicides; that's industry's role." All of this is true. But it's true this view relegates weed biology to archaeological midden heaps.

For weed scientists in the modern world, if you can't model, learn how. If applied research is taboo, think sacrilege. If you don't like herbicides, then show relevance to other types of management. The role of weed biology research is to facilitate weed management, an applied activity. Perhaps we can take a cue from the late Deng Xiaoping. If he was a Midwestern weed scientist, instead of leader of China, he might have said, "It doesn't matter if Buck the weed dog is black or white, as long as he controls weeds." (Couch potatoes know that Mr. Deng said, "It doesn't matter if the cat is black or white, as long as it catches mice," which referred to differing economic philosophies; and that Buck is Rhone-Poulenc's "weed dog," widely fearured in herbicide advertisements.) Like Mr. Deng, this statement is both pragmatic and politically asture, traits that weed biologists should adopt.

Two other examples of weed biology antiques go hand in hand. The first is seedling emergence from different soil depths, and the second is depth distributions of seeds in differing tillage systems. These studies are important for management, but have they ever been used to make management decisions? If not, how can we make better use of them? Equations can be constructed that describe seed burial depths according to tillage and seedling emergence according to burial depths. These equations can be combined to answer important questions. For instance, which tillage systems would minimize weed densities next spring if 1,000 seeds $\mathrm{m}^{-2}$ of giant foxtail were produced this summer? Simple calculations based on published information suggest that maximum seedling densities would be 870,700 , and 80 seedlings $\mathrm{m}^{-2}$ in zero-till, chisel plow, and moldboard plow (i.e., no-till, lo-till, and mo-till), respectively. If all else is equal, no-till should be the system least favored. However, if the species was Pennsylvania smartweed, instead of foxtail, maximum densities would be 330,410 , and 50 seedlings $\mathrm{m}^{-2}$ in the same systems. In this case, lo-till should be least favored. These seedling densities can also be used in programs such as HERB and WeedSoft to elicit recommendations, costs, and expected returns. Simple applications of biology might help keep our discipline thriving and more decisively affect people weed biologists need to influence.

Many other examples of unused weed biology could be described, but not here and now. To be even-handed, I must admit that applications of weed biology to weed management probably are far greater than generally appreciated. Much biological information becomes so ingrained with time that its apparent value is diminished. Examples are plentiful for weed biology: leaf surfaces, vascular transport, root uptake, inheritance, systematics, etc. Some of the charges leveled against weed biology have been overstated. But none of this should detract from my general message. Until weed biologists routinely demonstrate that their research affects control options and economic returns, we can expect little change in respondents' attitudes in future surveys of the contributions of weed biology to weed management. Naturally, no one researcher and no single research paper can fulfill all basic and applied roles simultaneously. But such fulfillment ought to be our goal.

Approved for publication April 7, 1997. 